\title{
Effect of Leucas aspera Against Aeromonas hydrophila in Nile Tilapia (Oreochromis niloticus): Immunity and Gene Expression Evaluation
}

\author{
Preetham Elumalai ${ }^{1^{*}}(\mathbb{D})$, Amitha Kurian ${ }^{1}\left(\mathbb{D}\right.$, Sreeja Lakshmi $\left.{ }^{1}{ }^{(}\right)$, Mohamed Saiyad \\ Musthafa $^{2}\left({ }^{\circ}\right.$, Einar Ringo ${ }^{3}\left(D\right.$, Caterina Faggio ${ }^{4}(\mathbb{C}$
}

${ }^{1}$ Kerala University of Fisheries and Ocean Studies, School of Ocean Science and Technology, Kochi/Kerala, India.

${ }^{2}$ The New College, Chennai, Department of Zoology, Chennai, India.

${ }^{3}$ The Arctic University, Faculty of Biosciences, Tromso, Norway.

${ }^{4}$ University of Messina, Department of Chemical, Biological, Pharmaceutical and Environmental Sciences, Messina, Italy.

\section{How to cite}

Elumalai, P., Kurian, A., Lakshmi, S., Musthafa, M.S., Ringo, E., Faggio, A. (2022). Effect of Leucas aspera Against Aeromonas hydrophila in Nile Tilapia (Oreochromis niloticus): Immunity and Gene Expression Evaluation. Turkish Journal of Fisheries and Aquatic Sciences, 22(2), TRJFAS19802. http://doi.org/10.4194/TRJFAS19802

\section{Article History}

Received 08 May 2021

Accepted 20 September 2021

First Online 27 September 2021

\section{Corresponding Author}

E-mail: preetham@kufos.ac.in

\author{
Keywords \\ Leucas aspera \\ Nile tilapia \\ Growth performance \\ Serum immunology \\ Disease resistance \\ Hematology
}

\begin{abstract}
The present study addressed the effects of Leucas aspera enriched diet in Nile tilapia. Three hundred Nile tilapia were fed Leucas aspera as follows: $0 \mathrm{~g} \mathrm{~kg}^{-1} \mathrm{~L}$. aspera (C-control), $5 \mathrm{~g} \mathrm{~kg}^{-1}$ L. aspera (T1), $10 \mathrm{~g} \mathrm{~kg}^{-1}$ L. aspera (T2) and $15 \mathrm{~g} \mathrm{~kg}^{-1}$ L. aspera (T3). After 30 days of feeding, significant $(P<0.05)$ increase in growth performance was noticed by feeding the fish the $\mathrm{T} 2$ diet. Thereafter fish were intraperitoneal injected with Aeromonas hydrophila in challenge test. After 21 days of challenge, highest survival rate $(70 \%)$ was observed in fish fed the T3 diet followed by fish fed T2 diet (65\%). Serum immunological parameters such as phagocytosis, alternative complement activity, respiratory burst activity and lysozyme activity were significantly $(P<0.05)$ enhanced in fish fed all inclusion levels of $L$. aspera with the maximum activity in fish fed the $T 2$ diet. Hematological parameters were significantly $(P<0.05)$ higher in all groups fed $L$. aspera diets vs. control fed fish. No histopathological changes in liver were observed in fish fed the $\mathrm{T} 2$ diet in the histology study. Gene expression study revealed the upregulation in the expression of COX-2 and GR genes. In conclusion, the current results suggest that dietary administration of $L$. aspera especially the $T 2$ diet, has beneficial effects in improving immunity and can mitigate the adverse effects of $A$. hydrophila infection in Nile tilapia.
\end{abstract}

\section{Introduction}

Aquaculture is one of the fastest growing industries in the world with China, India, Vietnam and Bangladesh being the major producers (FAO, 2017), but one major threat to the industry is the diseases, which causes economic loss and stunted development (Cabello et al., 2020). Previously, disinfectants, chemotherapeutics and antibiotics were used, but the consequences of these treatments were harmful (Ring $\varnothing$ et al., 2014; Seyfried et al., 2010). However, during the last decades research has focused on the application of novel ecofriendly and alternative supplements such as pro-, pre- and synbiotics, immunostimulants and medicinal herbs to improve fish growth, immune responses and disease resistance (Carbone and Faggio, 2016; Ring $\varnothing$ et al., 2014, 2018; de Santis et al., 2015; Musthafa et al., 2017, 2018; Awad and Awaad 2017; Nath et al., 2017; Van Doan et al., 2019; Elumalai et al., 2020). Of the functional food alternatives, plant derived compounds are promising, and are mainly categorized into tannins, alkaloids, pigments, essential oils, steroids, terpenoids, flavonoids and phenolics (Harikrishnan et al., 2011; Newaj-Fyzul and Austin, 2014; Reverter et al., 2014; Van Hai, 2015). Due to the abundance of secondary metabolites, dietary plant supplementations 
are suitable alternative to chemical treatments, as they have potential to prevent fish diseases (Hoseinifar et al., 2020; Rashidian et al., 2020; Van Doan et al., 2019). It is well known, that plant extracts contain immunostimulants, biocidal and anti-stress effects, as well as promoting fish growth (Wang et al., 2009; Harikrishnan et al., 2010; Wu et al., 2010; Yin et al., 2011).

Nile tilapia Oreochromis niloticus is a widely preferred fish species, and is one of the commonly cultured fish species in the world, produced in more than 100 countries (Gobi et al., 2018; Gu et al., 2015; van Doan et al., 2018). The global production was estimated to be 6.5 million metric tons in 2018 and is expected to reach 7.3 million metric tons by 2030 (Behera et al., 2018).

Aeromonas hydrophila, a Gram-negative bacterium is an aquatic pathogen that is distributed worldwide, and is an opportunistic pathogen producing symptoms such as tail and fin rot, ulcers etc. (Eddy, 2008; Tawwab and Abbass, 2017). As A. hydrophila is a primary bacterial pathogen in many aquatic organisms, it causes great concern to the aquaculture industry (Janda and Abbott, 2010; Mahmoud et al., 2017). It not only results in economic loss, but also has an impact on public health. A. hydrophila has the potential to grow at $5^{\circ} \mathrm{C}$, that points out its ability to exhibit public health hazards and they are associated with gastroenteritis, intestinal and extra-intestinal infections in humans (Praveen et al., 2016). Several previous investigations revealed the emergence of multidrug-resistant bacterial pathogens from different origins especially fish that increases the need for new natural immunostimulants and antimicrobial alternatives to the commonly used old antimicrobial agents (Algammal et al., 2020; Sayed et al., 2019; Abolghait et al., 2020; Enany et al., 2018).

Leucas aspera (Willd.) Linn. (Family: Lamiaceae) commonly known as 'thumbai' is distributed throughout India, and is traditionally used as an antipyretic and insecticide (Suganya et al., 2014). L. aspera contain medicinally active compounds such as triterpenoids, oleanolic acid, ursolic acid and b-sitosterol, nicotine, sterols, glucoside, diterpenes, phenolic compounds (4(24-hydroxy-1-oxo-5-n-propyltetracosanyl)-phenol) and hence is pharmacologically relevant (Antony et al., 2013). Flowers and leaves are valued as stimulant of menstrual flow, expectorant, aperient, diaphoretic and are considered useful in chronic rheumatism, psoriasis and other chronic skin eruptions (Prajapati et al., 2010). Banu et al. (2012) revealed that, L. aspera aqueous extract significantly elevated antioxidant enzymes and acted as a hepatoprotective agent against D-galactosamine induced liver damage in rats. Kripa et al. (2011) emphasized the anti-inflammatory and antioxidant potential in the $L$. aspera extract due to the presence of phytosterols, flavonoids (procyanidin and leucasin) and catechins apart from glycosides, phenolic compounds, and tannins and reported that ethanol extract helped in complete cartilage regeneration in adjuvant induced arthritic rats. A previous study revealed that, $L$. aspera extract encapsulated in Artemia nauplii enhanced the growth and survival rate of zebrafish (Danio rerio) (Teepica and Srinivasan, 2015). Similarly, Antony et al. (2013) reported that, L. aspera engineered silver nanoparticles promote hematological and antioxidant profile in catla (Catla catla) challenged with $A$. hydrophila. The current study aims to investigate the effects of $L$. aspera on growth, serum immunity, disease resistance, hematological profile and gene expression in Nile tilapia.

\section{Materials and Methods}

\section{Leucas aspera Powder Preparation}

L. aspera plants were grown at the campus of Kerala University of Fisheries and Ocean Studies in Kochi, India. The whole plant was collected, washed with tap water, shade dried and ground into fine powder described by Kurian et al. (2020).

\section{Fish Diets}

The experimental diets were prepared by supplementing different inclusion levels of $L$. aspera powder in the basal diet as follows: 0 (C-control), $5 \mathrm{~g} \mathrm{~kg}^{-1}$ (T1), $10 \mathrm{~g} \mathrm{~kg}^{-1}$ (T2) and $15 \mathrm{~g} \mathrm{~kg}^{-1}$ (T3) (Table 1). The diets were mixed evenly and dried in a vacuum freeze dryer for $15 \mathrm{~h}$. Thereafter all diets were ground properly and extruded by a $5 \mathrm{~mm}$ mesh sieve. The prepared diets were stored at $-20^{\circ} \mathrm{C}$ for two days until the start of the experiment.

\section{Study Design}

Nile tilapia used in the present study was transferred from a fish farm in Alleppey district, Kerala, to the laboratory. The fish were acclimated for two weeks in a $1000 \mathrm{~L}$ aerated fiber tank, and fed control diet as described by Kurian et al. (2020). After acclimation, 300 fish were randomly distributed into $15(150 \mathrm{~L})$ glass tanks (20 fish per tank; average weight $=8.11 \pm 0.05 \mathrm{~g}$ ), and cultured for 30 days with three replicates per treatment.

(i) Control group - Non- infected fish fed control diet without any L. aspera enrichment

(ii) Negative control - Fish fed control diet and challenged by $A$. hydrophila after 30 days of feeding

(iii) $5 \mathrm{~g} \mathrm{~kg}^{-1}$ - Control diet $+5 \mathrm{~g} / \mathrm{kg}$ L. aspera

(iv) $10 \mathrm{~g} \mathrm{~kg}^{-1}$ - Control diet $+10 \mathrm{~g} / \mathrm{kg}$ L. aspera

(v) $15 \mathrm{~g} \mathrm{~kg}^{-1}$ - Control diet $+15 \mathrm{~g} / \mathrm{kg}$ L. aspera

The fish were fed twice a day at 9.00 am and 5.00 pm ad libitum. Throughout the experiment, water quality parameters were monitored daily: water temperature $28 \pm 2^{\circ} \mathrm{C}, \mathrm{pH} 7.7 \pm 0.24$, and dissolved oxygen $5.1 \pm 0.31 \mathrm{mg} /$ liter. After 30 days of feeding, all treatment groups except group (i) were intraperitoneally injected with $A$. hydrophila. 
Table 1. Ingredients and composition of control and experimental diets

\begin{tabular}{|c|c|c|c|c|}
\hline \multirow{2}{*}{ Ingredients $\left(\mathrm{g} \mathrm{kg}^{-1}\right)$} & \multicolumn{4}{|c|}{ Diet groups \% } \\
\hline & $\mathrm{C}$ & $\mathrm{T} 1\left(5 \mathrm{~g} \mathrm{Kg}^{-1}\right)$ & T2 $\left(10 \mathrm{~g} \mathrm{Kg}^{-1}\right)$ & T3 $\left(15 \mathrm{~g} \mathrm{Kg}^{-1}\right)$ \\
\hline Fish meal & 270 & 270 & 270 & 270 \\
\hline Corn meal & 200 & 199 & 203 & 206 \\
\hline Soybean meal & 270 & 270 & 270 & 270 \\
\hline Wheat flour & 60 & 60 & 60 & 60 \\
\hline Rice bran & 150 & 150 & 150 & 150 \\
\hline L. aspera & 0 & 5 & 10 & 15 \\
\hline Cellulose & 30 & 26 & 17 & 9 \\
\hline Soybean oil & 5 & 5 & 5 & 5 \\
\hline Premix ${ }^{1}$ & 10 & 10 & 10 & 10 \\
\hline Vitamin $C^{2}$ & 5 & 5 & 5 & 5 \\
\hline \multicolumn{5}{|c|}{ Proximate composition of the experimental diets ( $\mathrm{g} \mathrm{Kg}^{-1}$ dry matter basis) } \\
\hline Dry matter & 88.25 & 89.07 & 94.05 & 93.33 \\
\hline Ash & 9.13 & 9.32 & 9.70 & 9.73 \\
\hline Crude Fibre & 2.47 & 2.26 & 3.06 & 3.43 \\
\hline Crude lipid & 6.36 & 6.86 & 6.44 & 7.24 \\
\hline Crude protein & 30.5 & 31.4 & 33.8 & 32.7 \\
\hline GE $(\text { Cal g-1 })^{c}$ & 4020 & 4075 & 4151 & 4240 \\
\hline
\end{tabular}

Note: ${ }^{a}$ Vitamin premix per kg: Vitamin A=700000 IU; Vitamin $\mathrm{D}=140000 \mathrm{IU}$; Vitamin E=500mg; Vitamin $\mathrm{B}_{12}=1000 \mathrm{mcg}$; Folic acid=100mg;

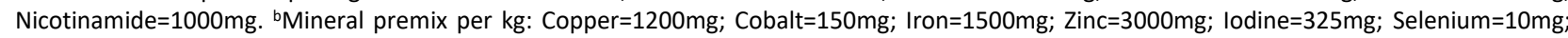
Magnesium=6000mg; Manganese=1500mg; Potassium=100mg; Calcium=270gm; Phosphorus=130gm; Sulphur=7.2gm; Fluorine=300mg. ${ }^{\mathrm{c}} \mathrm{GE}=$ Gross energy

\section{Pathogen}

A. hydrophila (ATCC 49140) isolated from infected fish was supplied by Aquatic Animal Health Laboratory (AAHL) of C. Abdul Hakeem College located in Melvisharam, Vellore, Tamil Nadu, India and was cultured in tryptic soy broth (TSB, Himedia) for $24 \mathrm{~h}$ at $37^{\circ} \mathrm{C}$ with agitation to mid-log growth phase (Musthafa et al., 2018). The broth culture was centrifuged for 10 minutes at $3.000 \mathrm{~g}$. The supernatant was discarded and the pellet was washed twice with $0.15 \mathrm{M}$ phosphate buffered saline (PBS, pH 7.2). The bacterial pellets were re-suspended and divided into aliquots and stored in (TSB) supplemented with $15 \%(\mathrm{v} / \mathrm{v})$ glycerol and stored at $-70^{\circ} \mathrm{C}$ until further use. Optical density $\left(O D_{456}\right)$ of the solution was adjusted to 0.5 , which corresponds to $1 \times 10^{7}$ cells $\mathrm{ml}^{-1}$. The bacterial suspensions were serially diluted using standard dilution technique with PBS and used in the challenge experiment.

\section{Challenge Test}

After 30 days of feeding, all groups except group (i) were challenged intraperitoneally with $100 \mu \mathrm{l}$ PBS containing $A$. hydrophila $\left(1 \times 10^{7}\right.$ cells $\left.\mathrm{mL}^{-1}\right)$. Mortality was noted every $12 \mathrm{~h}$ interval up to 21 days and dead fish were removed immediately (Musthafa et al., 2018). Survival rate (SR) was calculated using the formulae:

SR (\%)=(final fish number/initial fish number) $\times 100$.

\section{Blood Sampling and Preparation}

Six fish were selected randomly from each replication at the end of the challenge test. Fish were anaesthetized with $0.1 \mathrm{ppm}$ MS-222 (Sigma chemicals), and blood was collected from the caudal vein with a 1 $\mathrm{ml}$ plastic syringe coated with heparin and stored at $4^{\circ} \mathrm{C}$ until the next day. Blood samples collected without heparin were allowed to clot for $2 \mathrm{~h}$ at $4^{\circ} \mathrm{C}$, centrifuged at $3.500 \mathrm{~g}$ at $4^{\circ} \mathrm{C}$ for 25 minutes, sera collected and refrigerated. Leukocytes were separated from peripheral blood by the method described by Van Doan et al. (2016).

\section{Hematological Parameters}

Hematological parameters were determined according to Nya and Austin (2009).

\section{Phagocytosis Activity}

The phagocytic activity assay was performed as described by van Doan et al. (2018). $200 \mathrm{ml}$ leukocyte suspensions $2 \times 10^{6}$ cells $\mathrm{ml}^{-1}$ were spread on coverslips and incubated for $2 \mathrm{~h}$. Non-adherent cells were then removed by washing with RPMI 1640. $200 \mathrm{ml}$ of fluorescence latex beads (Sigma) solution $2 \times 10^{7}$ of beads $\mathrm{mL}^{-1}$ was added on each coverslip and incubated for 1.5 $\mathrm{h}$ at room temperature. After incubation, the nonphagocytized beads were washed with RPMI 1640. The coverslips were then fixed with methanol and stained with Diff-Quick staining dye (Sigma) for 10 seconds. The excess stain was removed by washing with PBS ( $\mathrm{pH} 7.4)$, and the number of phagocytized cells per 300 adhered cells was counted microscopically. The phagocytic index (PI) was determined as follows: $\mathrm{PI}=$ Average number of beads per cell divided by the number of phagocytizing cells. 


\section{Alternative Complement Activity}

Alternative complement pathway activity ( $\mathrm{ACH} 50)$ was determined according to Yanno (1992). Rabbit red blood cells (R-RBC) were washed thrice in $0.01 \mathrm{M}$ ethylene glycol tetra-acetic acid-magnesium-gelatin veronal buffer (0.01M-EGTA-Mg-GVB), and the concentration was adjusted to $2 \times 10^{8}$ cells $\mathrm{ml}^{-1}$ in the same buffer. Exactly $100 \mathrm{ml}$ of the suspension was lysed with $3.4 \mathrm{ml}$ of distilled water. The absorbance of hemolysate was measured at $414 \mathrm{~nm}$ against distilled water blank and was brought to be close to 0.740 . For the $\mathrm{ACH} 50$ test, $100 \mathrm{ml}$ of test serum was diluted with $400 \mathrm{ml}$ of $0.01 \mathrm{M}-\mathrm{EGTA}-\mathrm{Mg}-\mathrm{GVB}$, and serial two-fold dilution was made. Consequently, $100 \mathrm{ml}$ of R-RBC suspension was added to each tube and incubated at $20^{\circ} \mathrm{C}$ for $90 \mathrm{~min}$ with occasional shaking. After incubation, $3.15 \mathrm{ml}$ of cold saline was added to each tube and centrifuged at $1600 \mathrm{~g}$ for $5 \mathrm{~min}$. One hundred $\mathrm{ml}$ of the supernatant of each dilution was then transferred to 96 -well plate and read at $414 \mathrm{~nm}$. The degree of hemolysis was calculated by dividing the corrected absorbance 414 value by the corrected absorbance 414 of the $100 \%$ hemolysis control. The degree of hemolysis and the serum volume were plotted on a log paper. The volume of serum that gave $50 \%$ hemolysis was used for calculating the $\mathrm{ACH} 50$ using the formula: $\mathrm{ACH} 50$ (units $/ \mathrm{ml}$ ) $=1 / \mathrm{K} \times \mathrm{r} \times 1 / 2$, where $\mathrm{K}$ is the amount of serum giving $50 \%$ hemolysis, $r$ is the reciprocal of the serum dilution, and $1 / 2$ is the correction factor.

\section{Respiratory Burst Activity}

Respiratory burst activity was carried out as described by Secombes (1990) for measuring the production of oxygen radicals from phagocytes. $0.1 \mathrm{~mL}$ of heparinized blood was placed into a microtiter plate and equal amount of $0.2 \%$ NBT was added and incubated for 30 minutes at room temperature. $0.05 \mathrm{~mL}$ of the NBT-blood cell suspension was taken out and added to a glass tube containing $1.0 \mathrm{~mL}$ of $\mathrm{N}, \mathrm{N}$ dimethylformamide solution. Then the mixture was centrifuged for 5 minutes at $3.000 \mathrm{~g}$. The supernatant was taken into a glass cuvette and absorbance was read at $540 \mathrm{~nm}$ using a spectrophotometer.

\section{Lysozyme Activity}

Lysozyme activity was determined by the protocol of Parry et al. (1965). Briefly, $25 \mu \mathrm{L}$ of mucus and serum loaded into 96 -well plate in triplicate. Then, $175 \mu \mathrm{L}$ of Micrococcus lysodeikticus (Sigma Aldrich - USA) suspension $\left(0.3 \mathrm{mg} \mathrm{mL}^{-1}\right.$ in $0.1 \mathrm{M}$ citrate phosphate buffer, pH 5.8) was added to each well. After the rapid mixing, change in turbidity was detected every 30 seconds for $5 \mathrm{~min}$ at $540 \mathrm{~nm}$ and $25^{\circ} \mathrm{C}$ using a microplate reader. The equivalent unit of activity of the sample (compared with the standard) was determined and expressed as $\mu \mathrm{g} \mathrm{mL}^{-1}$ serum. The serum lysozyme activity was measured and expressed as $\mathrm{U} \mathrm{mL}^{-1}$.

\section{Histology}

For histopathology study of liver, tissues from fish fed $10 \mathrm{~g} \mathrm{~kg}^{-1} \mathrm{~L}$. aspera enriched diet were processed following the methods by Humason (1979) and Pearse (1968). Liver was fixed for 24 hours in $10 \%$ formalin solution before embedding in paraffin wax. Sections of liver were stained with hematoxylin and eosin and were analyzed for histopathological alterations.

\section{RNA Extraction, cDNA Synthesis and Real Time-PCR}

For gene expression studies, spleen of fish fed $10 \mathrm{~g}$ $\mathrm{kg}^{-1}$ L. aspera enriched diet was collected. RNA was extracted using TRIzol (Sigma). Purity and quality of RNA was detected using Nanodrop (Thermo Fisher Scientific) as the 260:280 ratio was 1.8-2.0. Afterward, complementary DNA (cDNA) was synthesized using cDNA synthesis kit (iScript cDNA synthesis kit, Bio-Rad) according to the manufacturer's protocol. Specific primers for gene expression were designed using primer premier 5 software to amplify the selected genes with $\beta$-actin as a house keeping gene (Table 4). The q RT-PCR analysis was carried out using CFX96 Touch Real time PCR detection system (Bio- Rad) and Sso Advanced Universal SYBR green supermix (Bio-Rad) following the manufacturer's instructions and as per the method described by Mahfouz (2015).

\section{Growth Performance}

Growth performance was calculated at the end of the feeding trial. Weight gain (WG), specific growth rate (SGR) and feed conversion ratio (FCR) were calculated using the formulae:

$$
\begin{gathered}
\text { WG }=\text { final weight }(g)-\text { initial weight }(g) ; \\
S G R(\%)=100 \times(\text { In final weight }- \text { In initial weight }) / \\
\text { Duration of experiment; } \\
F C R=\text { feed given (dried weight)/weight gain (wet } \\
\text { weight); }
\end{gathered}
$$

\section{Statistical Analysis}

The data of each parameter were expressed as the mean \pm standard error of mean (SEM) and the effects of experimental diets were tested using one-way analysis of variance (ANOVA) followed by Tukey's pairwise comparison test using SPSS (version 16 for windows). Differences were considered statistically significant when $(P<0.05)$. 


\section{Results}

\section{Growth Performance}

Growth performance was assessed after 30 days of feeding. Weight gain (WG), specific growth rate (SGR) and feed conversion ratio (FCR) were significantly $(\mathrm{P}<0.05)$ improved in fish fed $L$. aspera diets compared to control. Tilapia fed $10 \mathrm{~g} \mathrm{~kg}^{-1}$ diet (T2) displayed the best growth performance among the treatment groups (Table 2).

\section{Hematological Profile}

The erythrocyte (RBC) and leukocyte (WBC) levels were significantly $(P<0.05)$ higher in the fish fed $L$. aspera diets vs. fish fed the control diet (Table 3 ). Highest erythrocyte number (6.70 \pm 0.0$)$ was observed in fish fed $10 \mathrm{~g}$ L. aspera $\mathrm{kg}^{-1}$ (T2) vs. the control. Similarly, significant $(\mathrm{P}<0.05)$ higher numbers of all other erythrocyte parameters; hemoglobin $(\mathrm{Hb})$, packed cell volume (PCV), mean corpuscular volume (MCV), mean corpuscular hemoglobin $(\mathrm{MCH})$, mean corpuscular hemoglobin concentration ( $\mathrm{MCHC}$ ) were recorded in all L. aspera treatment groups compared to the control, with the highest value in group fed $10 \mathrm{~g} L$. aspera $\mathrm{kg}^{-1}$. Fish fed dietary L. aspera affected the proportions of neutrophil, lymphocyte, monocyte and eosinophil. Highest value of neutrophil was revealed in the group fed $5 \mathrm{~g}$ L. aspera $\mathrm{kg}^{-1}$ compared to the other treatment groups. However, a decrease in percentage of lymphocyte and monocyte levels was observed in all treatment groups including the control at all-time points (Table 3).

\section{Phagocytic Activity}

All administrations of $L$. aspera revealed significantly $(\mathrm{P}<0.05)$ higher phagocytic activity vs. control group. However, the maximum activity is revealed in fish fed $10 \mathrm{~g}$ L. aspera $\mathrm{kg}^{-1}$ followed by fish fed $15 \mathrm{~g} \mathrm{~kg}^{-1}$ and $5 \mathrm{~g} \mathrm{~kg}^{-1}$ (Figure 1).

\section{Complement Activity}

Figure 2 shows a significant $(P<0.05)$ increase in complement activity in Nile tilapia by all doses of L. aspera, and administration of $10 \mathrm{~g}$ L. aspera $\mathrm{kg}^{-1}$ revealed the highest complement activity $v s$. the control group.

\section{Respiratory Burst Activity}

Maximum respiratory burst activities of phagocytes were exhibited by fish fed $10 \mathrm{~g} \mathrm{~kg}^{-1}$ followed by $15 \mathrm{~g} \mathrm{~kg}^{-1}$ feed (Figure 3 ). All the inclusions levels of $L$. aspera revealed significant $(\mathrm{P}<0.05)$ increase in respiratory burst activity compared with the control.

Table 2. Growth performance of $O$. niloticus fed $L$. aspera supplementation diets against $A$. hydrophila after 30 days

\begin{tabular}{lcccc}
\hline Parameters & Control & $5 \mathrm{~g} \mathrm{~kg}^{-1}$ & $10 \mathrm{~g} \mathrm{~kg}^{-1}$ & $15 \mathrm{~g} \mathrm{~kg}^{-1}$ \\
\hline IW (g) & $8.10 \pm 0.01$ & $8.10 \pm 0.01$ & $8.11 \pm 0.01$ & $8.13 \pm 0.01$ \\
FW (g) & $44.46 \pm 1.16$ & $51.96 \pm 1.0^{*}$ & $58.50 \pm 0.51^{*}$ & $50.9 \pm 0.55^{*}$ \\
WG (g) & $36.36 \pm 1.17$ & $43.86 \pm 1.01^{*}$ & $50.39 \pm 0.51^{*}$ & $42.77 \pm 0.61^{*}$ \\
SGR (g) & $3.77 \pm 0.06$ & $4.12 \pm 0.04^{*}$ & $4.38 \pm 0.01^{*}$ & $4.07 \pm 0.02^{*}$ \\
FCR & $1.57 \pm 0.01$ & $1.55 \pm 0.02^{*}$ & $1.49 \pm 0.01^{*}$ & $1.53 \pm 0.02^{*}$ \\
\hline
\end{tabular}

$\mathrm{IW}=$ Initial weight, $\mathrm{FW}=$ Final weight, $\mathrm{SGR}=$ Specific growth rate, FCR = Feed conversion ratio. The values are expressed as mean \pm standard errors of mean.

Table 3. Immuno-haematological parameters of $O$. niloticus fed Leucas aspera supplementation diets against $A$. hydrophila

\begin{tabular}{|c|c|c|c|c|c|c|c|c|c|}
\hline Parameters & $\begin{array}{c}\text { Control } \\
\left(0 \mathrm{~g} \mathrm{~kg}^{-1}\right)\end{array}$ & $\begin{array}{c}\text { Negative } \\
\text { Control }\end{array}$ & $\begin{array}{l}\text { Percent } \\
\text { change }\end{array}$ & $5 \mathrm{~g} \mathrm{~kg}^{-1}$ & $\begin{array}{l}\text { Percent } \\
\text { Change }\end{array}$ & $10 \mathrm{~g} \mathrm{~kg}^{-1}$ & $\begin{array}{l}\text { Percent } \\
\text { Change }\end{array}$ & $15 \mathrm{~g} \mathrm{~kg}^{-1}$ & $\begin{array}{l}\text { Percent } \\
\text { Change }\end{array}$ \\
\hline Erythrocyte & & & Con. VS & & Con. VS & & Con. VS & & Con. VS \\
\hline profile & & & Neg.Con. & & $5 \mathrm{~g} \mathrm{~kg}^{-1}$ & & $10 \mathrm{~g} \mathrm{~kg}^{-1}$ & & $15 \mathrm{~g} \mathrm{~kg}^{-1}$ \\
\hline $\mathrm{RBC}\left(\times 10^{6} \mathrm{~mm}^{3}\right)$ & $2.30 \pm 0.0$ & $1.10 \pm 0.0$ & $-52.17 \downarrow$ & $2.80 \pm 0.3$ & $21.73 \uparrow$ & $6.70 \pm 0.0^{*}$ & $191.30 \uparrow$ & $3.50 \pm 0.2$ & $52.17 \uparrow$ \\
\hline $\mathrm{Hb}\left(\mathrm{g} \mathrm{dL}^{-1}\right)$ & $8.60 \pm 0.3$ & $6.30 \pm 0.1$ & $-26.74 \downarrow$ & $8.70 \pm 0.0$ & $1.16 \uparrow$ & $14.60 \pm 0.1^{*}$ & $69.76 \uparrow$ & $10.5 \pm 0.0^{*}$ & $22.09 \uparrow$ \\
\hline PCV (\%) & $33.5 \pm 1.7$ & $12.3 \pm 1.0$ & $-63.28 \downarrow$ & $39.0 \pm 1.7$ & $16.41 \uparrow$ & $47.5 \pm 3.8^{*}$ & $41.79 \uparrow$ & $41.5 \pm 2.5^{*}$ & $23.88 \uparrow$ \\
\hline MCV (fI) & $120.2 \pm 6.3$ & $78.5 \pm 5.3^{*}$ & $-34.69 \downarrow$ & $145.2 \pm 7.0$ & $20.79 \uparrow$ & $162.5 \pm 3.7^{*}$ & $35.19 \uparrow$ & $149.5 \pm 5.3^{*}$ & $24.37 \uparrow$ \\
\hline $\mathrm{MCH}(p g)$ & $22.3 \pm 1.5$ & $15.5 \pm 1.2^{*}$ & $-30.49 \downarrow$ & $38.9 \pm 1.0$ & $74.43 \uparrow$ & $61.2 \pm 2.9^{*}$ & $174.43 \uparrow$ & $45.2 \pm 1.7^{*}$ & $102.69 \uparrow$ \\
\hline $\mathrm{MCHC}\left(\mathrm{g} \mathrm{dL}^{-1}\right)$ & $28.7 \pm 0.1$ & $18.4 \pm 0.5^{*}$ & $-35.88 \downarrow$ & $34.5 \pm 0.5$ & $20.20 \uparrow$ & $56.0 \pm 2.6^{*}$ & $95.12 \uparrow$ & $42.5 \pm 2.7^{*}$ & $48.08 \uparrow$ \\
\hline \multicolumn{10}{|l|}{ Leukocyte profile } \\
\hline $\mathrm{WBC}\left(\times 10^{3} \mathrm{~mm}^{3}\right)$ & $22.50 \pm 0.32$ & $17.10 \pm 0.1$ & $-24.00 \downarrow$ & $27.50 \pm 0.3$ & $22.22 \uparrow$ & $35.50 \pm 0.6^{*}$ & $57.77 \uparrow$ & $29.10 \pm 0.2^{*}$ & $29.33 \uparrow$ \\
\hline Neutrophil (\%) & $26.25 \pm 0.17$ & $32.32 \pm 0.1^{*}$ & $23.12 \uparrow$ & $43.00 \pm 0.6^{*}$ & $63.80 \uparrow$ & $40.00 \pm 0.6$ & $52.38 \uparrow$ & $36.40 \pm 0.5$ & $38.66 \uparrow$ \\
\hline Lymphocyte (\%) & $70.50 \pm 1.35$ & $64.62 \pm 1.1$ & $-8.34 \downarrow$ & $54.15 \pm 1.5$ & $-23.19 \downarrow$ & $56.65 \pm 1.5$ & $-19.64 \downarrow$ & $60.15 \pm 1.2$ & $-14.68 \downarrow$ \\
\hline Monocyte (\%) & $2.25 \pm 0.05$ & $1.64 \pm 0.0 *$ & $-27.11 \downarrow$ & $1.60 \pm 0.03^{*}$ & $-28.88 \downarrow$ & $2.00 \pm 0.03$ & $-11.11 \downarrow$ & $2.20 \pm 0.0$ & $-2.22 \downarrow$ \\
\hline Eosinophil (\%) & $1.00 \pm 0.02$ & $1.26 \pm 0.0$ & $26.00 \uparrow$ & $1.25 \pm 0.01$ & $25.00 \uparrow$ & $1.35 \pm 0.01 *$ & $35.00 \uparrow$ & $1.25 \pm 0.0$ & $25.00 \uparrow$ \\
\hline
\end{tabular}

The superscript symbols in the same line show that there are significant differences among different experimental group $(P<0.05)$.

*Values are means \pm SD ( $n=6$ in three replicates).

$\uparrow$ Symbols indicates the increase percentage of respective parameters.

$\downarrow$ Symbols indicates the decrease percentage of respective parameters. 
Table 4. Primers used for real time PCR

\begin{tabular}{lccc}
\hline Gene & Sequence & Product size (bp) & Reference \\
\hline GR & $\begin{array}{c}\text { F: CATTACCGAGACGCGGAGTT } \\
\text { R: CAGTTGGCTCAGGATCATTTGT }\end{array}$ & 420 & Yilmaz et al \\
\hline$\beta$-actin & $\begin{array}{l}\text { F: ACAGGATGCAGAAGGAGATCACAG } \\
\text { R: GTACTCCTGCTTGCTGATCCACAT }\end{array}$ & 155 & Zhi et al \\
\hline COX-2 & $\begin{array}{l}\text { F: AGCAGCCAGAAGGAAGGCGG } \\
\text { R: GACTGAGTTGCAGTTCTCTTAGTGTGC }\end{array}$ & 130 & Chuang and Pan \\
\hline
\end{tabular}

\section{Lysozyme Activity}

The lysozyme activity was significantly $(P<0.05)$ increased in serum, liver and kidney of fish fed the $L$. aspera diets vs. with the control. The highest activity was observed in fish fed $10 \mathrm{~g} \mathrm{~kg}^{-1}$ diet (Figure 4).

\section{Disease Resistance}

The survival rates after challenging with $A$. hydrophila was $55 \%$ (5g kg-1 group), 65\% (10 $\mathrm{g} \mathrm{kg}^{-1}$ group), $70 \%\left(15 \mathrm{~g} \mathrm{~kg}^{-1}\right)$ and $30 \%$ in fish fed the control diet (Figure 5). Among the L. aspera supplemented groups, survival rate was significantly $(P<0.05)$ highest in fish fed $15 \mathrm{~g} / \mathrm{kg}^{-1}$.

\section{Histology}

Effects of dietary L. aspera on liver histology of control and treatment group ( $10 \mathrm{~g} \mathrm{~kg}^{-1}$ diet) are shown in Figure $6 a-b$. In the treatment groups, histological analysis of liver revealed normal architectural arrangement with abundant hepatocytes (H) with prominent nucleus and sinusoids (SI).

\section{Gene Expression}

The results of immune gene expression are shown in Figure $7 \mathrm{a}-\mathrm{b}$. In fish fed the $10 \mathrm{~g} \mathrm{~kg}^{-1}$ diet, expression of cyclooxygenase-2 (COX-2) and glutathione reductase (GR) was upregulated.

\section{Discussion}

The present study addressed the potential of $L$. aspera to stimulate growth, immunity, and disease resistance against $A$. hydrophila in Nile tilapia.

In a previous study, Teepica and Srinivasan (2015) reported higher survival rate (92.45\%) and SGR (2.52\%) by feeding zebrafish bioencapsulated Artemia nauplii with L. aspera extract. Moreover, it has also been revealed that ethanol extract of $L$. aspera enhanced the anti-inflammatory and antioxidant potential in adjuvant arthritis female wistar rats and Swiss albino mice of both sexes (Kripa et al., 2011).

Dietary supplementations of medicinal plants enhance growth performance of fish species (Ahmadifar et al., 2019; Gholampour et al., 2020; Rashidian et al., 2019). Recently, two studies (Musthafa et al., 2017,
2018) reported that the inclusion of calabaza (Cucurbita mixta) and velvet bean (Mucuna pruriens) seed meal at inclusion level of $4 \mathrm{~g} \mathrm{~kg}^{-1}$ and $6 \mathrm{~g} \mathrm{~kg}^{-1}$ significantly $(P<0.05)$ increased FCR, SGR, feed efficiency (FE), and protein efficiency ratio (PER) in Mossambicus tilapia Oreochromis mossambicus. Similarly, Mahmoud et al. (2017) reported effect of dietary curcumin (Curcuma longa) in tilapia against $A$. hydrophila and revealed that among the five diets used $(0,50,100,150$ and $200 \mathrm{mg} \mathrm{kg}$ $\left.{ }^{1}\right)$, the $50 \mathrm{mg} \mathrm{kg}^{-1}$ diet significantly improved the final weight, daily weight gain and SGR. In the present study, a significant $(P<0.05)$ increase in weight gain, FCR and SGR were observed by feeding tilapia $10 \mathrm{~g}$ L. aspera $\mathrm{kg}^{-1}$ compared to the other experimental groups, and revealed that dietary $L$. aspera supplementation has the potential of being a growth-promoting additive.

Hematological profile can be utilized as an indicator to evaluate the physiological status of fish (Burgos Aceves et al., 2019). The increase in RBC count noticed in the present study might be an indicator of the immunostimulant effect of $L$. aspera, and changes in the $W B C$ levels indicate response to infections. Elevation in the level of WBC indicates the activation of defense mechanism in response to microbial attack. Increment in neutrophil levels indicates activation of defense mechanism. Level of hemoglobin gives an index on RBC function and severity of anemia can be determined from the hemoglobin level. Rise in hemoglobin content indicates increased oxygen transportation. In the present study, all erythrocyte parameters were higher in all treatment groups than the control.

Phagocytosis is a prime factor that protects the host from invading microbes (Musthafa et al., 2018). Enhanced phagocytosis has been previously reported in studies where herbal immunostimulants were included in fish feed. In a recent study, Mbokane and Moyo (2018) reported that African worm wood (Artemisia afra) leaf powder supplemented at $9 \%$ and $12 \%$ levels increased phagocytosis activity in Mossambicus tilapia. The result of the current study revealed that $L$. aspera is an enhancer of phagocytosis activity.

Complement system provides the host with vital antimicrobial defense (Van Hai, 2015). Complement pathway has bactericidal activities mainly reported in fish serum and is antibody independent. On the other hand, $T$ cells and $T$ cell receptors, $B$ cells and immunoglobulins, and lymphocytes are the specific immune elements in fish. Cytokines, also act in modulating the immune response and are connected 


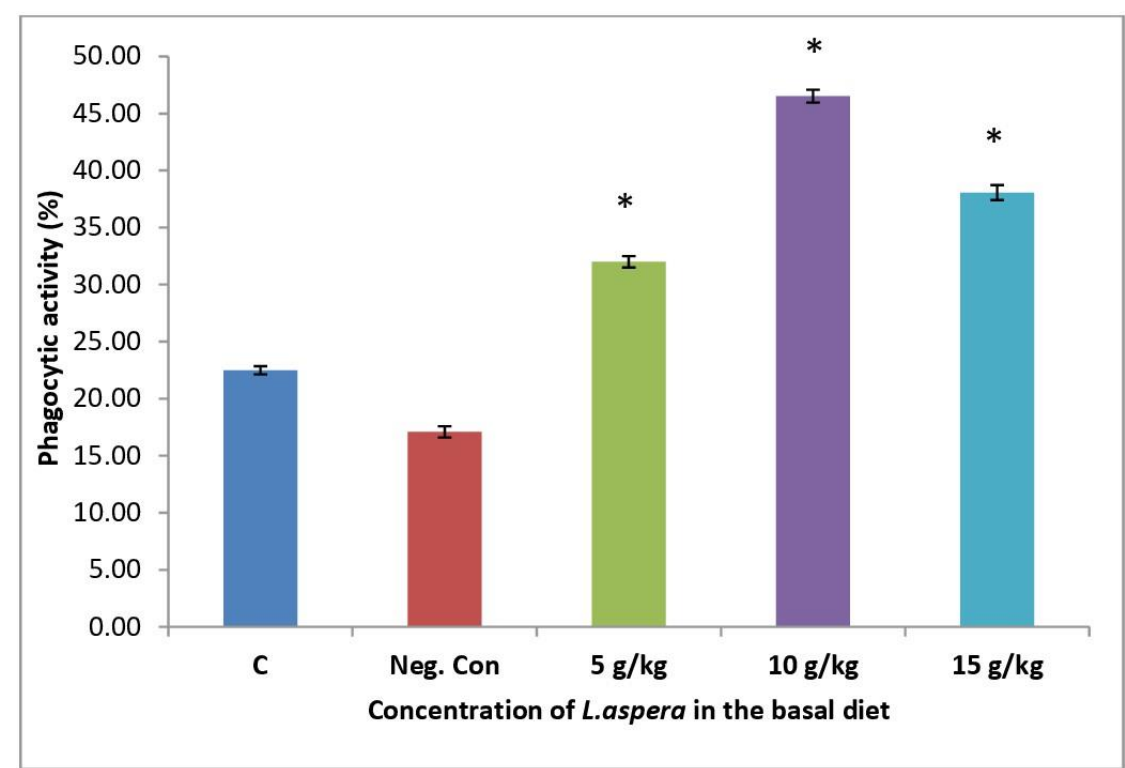

Figure 1. Phagocytic activity (\%) of freshwater fish $O$. niloticus (mean $\pm S E M, n=3$ ) fed experiment diets containing $L$. aspera in different levels for 30 days. Significant difference $(P<0.05)$ from the control is indicated by asterisks.

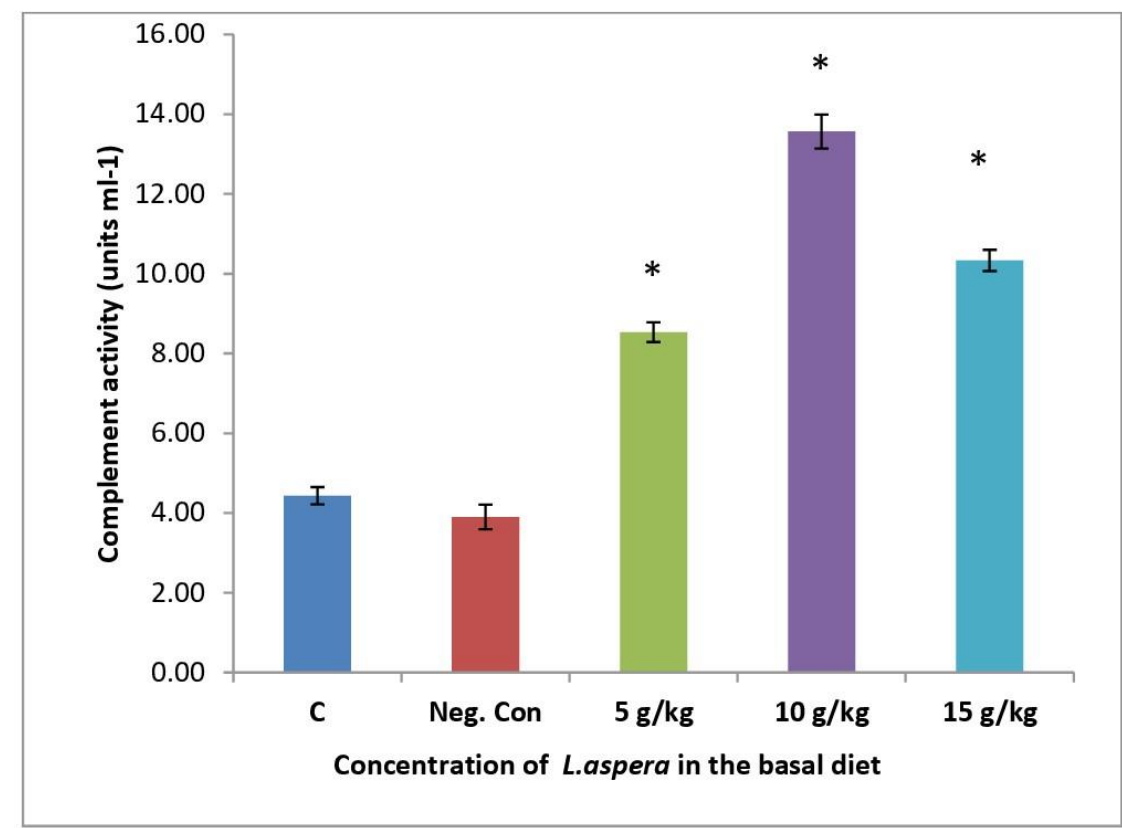

Figure 2. Complement activity (Units/ml) of freshwater fish $O$. niloticus (mean $\pm S E M, n=3$ ) fed experiment diets containing $L$. aspera in different levels for 30 days. Significant difference $(P<0.05)$ from the control is indicated by asterisks.

with innate and adaptive immunity (Magnadottir, 2006). Thus, with the aid of the immune elements, fish immune system protects the host from the attack of pathogens (Zapata et al., 2006; Bruce and Brown, 2017). The results of the present study revealed that inclusion of $L$. aspera activate the complement system that is crucial in recruiting phagocytes and elimination of pathogens.

Production of oxidative radicals, peroxidase and activation of neutrophils account to the non-specific defense mechanism in fish as oxidative burst or respiratory burst, different cells release reactive oxygen species that are noxious for bacterial pathogens (Ainsworth et al., 1991; Semple et al., 2018). In this context, it is worth to notice that Nile tilapia fed the $L$. aspera enriched diets significantly $(P<0.05)$ increased respiratory burst activity of phagocytes and that $L$. aspera enriched diets stimulated phagocytic cell membrane, and production of reactive oxygen species that are toxic to pathogens.

Lysozyme, a non-specific immune element acts on the peptidoglycan layer of bacteria resulting in lysis (Yousefi et al., 2019). In fish, lysozyme is mainly produced by the liver, and its presence can be detected in mucus, plasma and other fluids (Van Doan et al., 2019). In the present study, significant $(P<0.05)$ increase in the lysozyme activity was observed in the serum, liver 


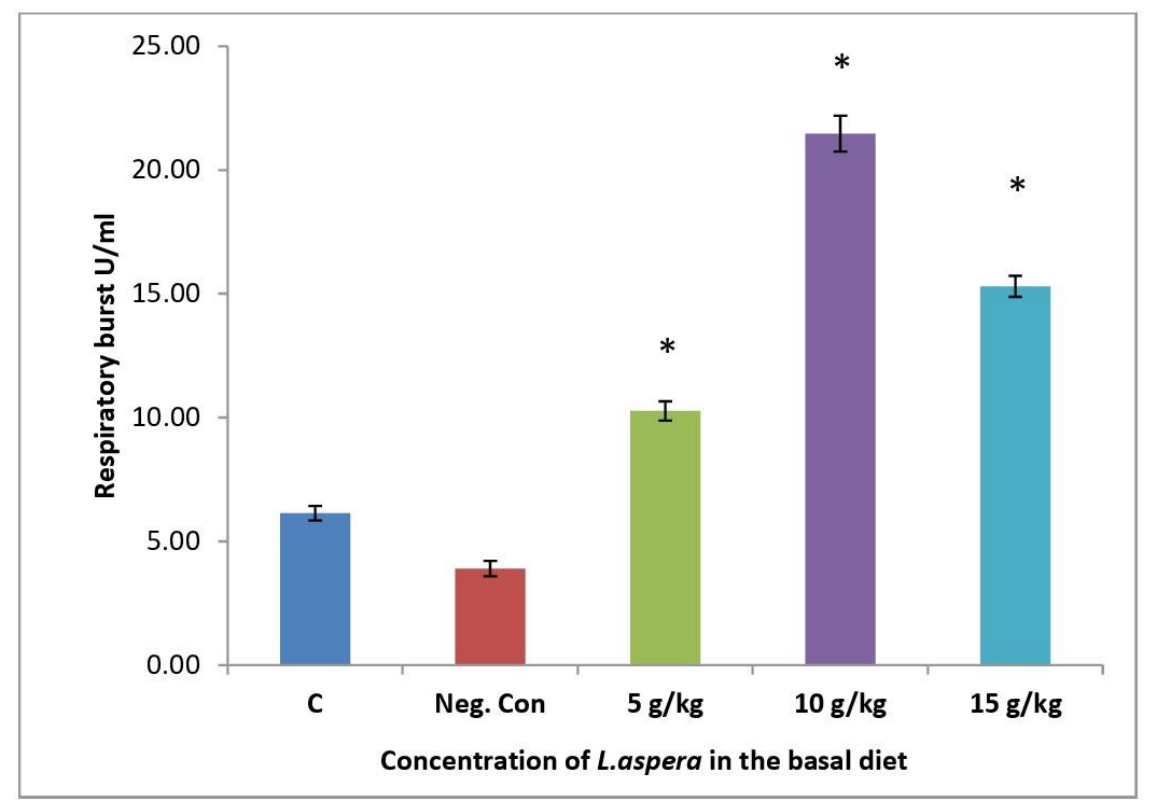

Figure 3. Respiratory burst activity $(\mathrm{U} / \mathrm{ml})$ of freshwater fish $O$. niloticus (mean $\pm S E M, n=3)$ fed experiment diets containing L. aspera in different levels for 30 days. Significant difference $(P<0.05)$ from the control is indicated by asterisks.

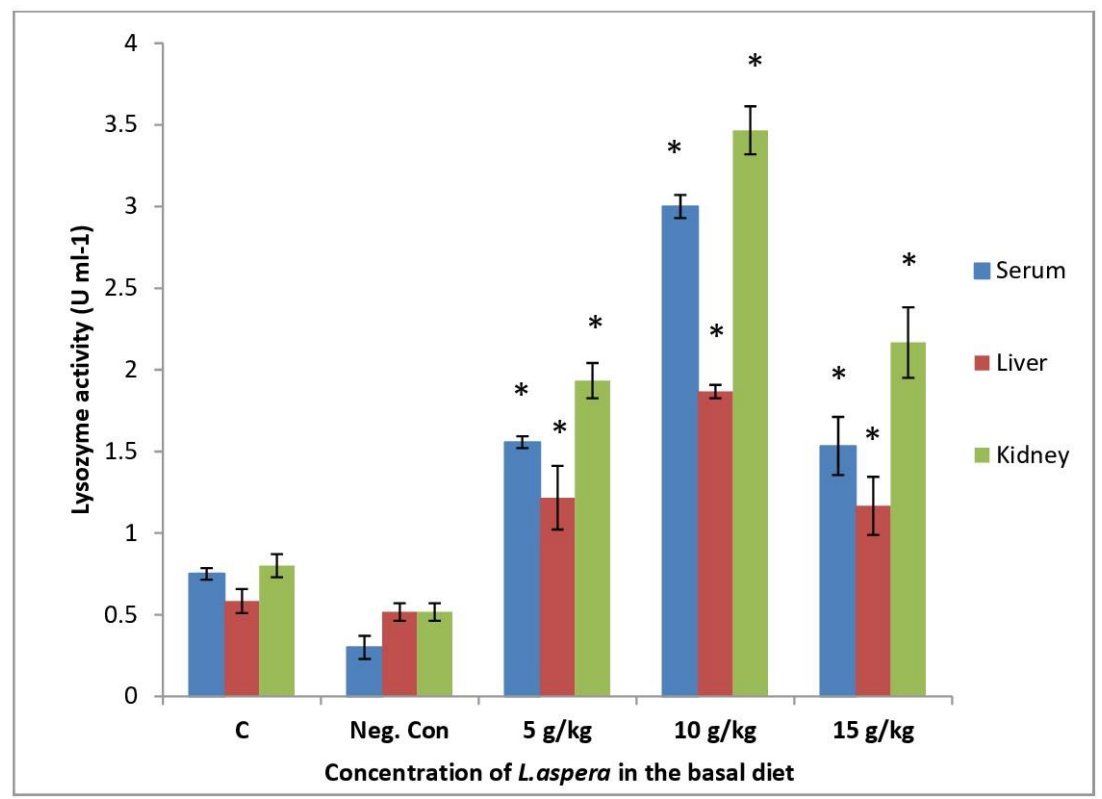

Figure 4. Lysozyme activity $\left(\mathrm{U} \mathrm{ml}^{-1}\right)$ of freshwater fish $O$. niloticus (mean $\pm \mathrm{SEM}, \mathrm{n}=3$ ) fed experiment diets containing $L$. aspera in different levels for 30 days. Significant difference $(P<0.05)$ from the control is indicated by asterisks.

and kidney samples fish fed different inclusion levels of L. aspera in the diets vs. control group, and indicate that L. aspera administration improved involvement of lysozyme in defense mechanisms in Nile tilapia.

Polyphenols of $L$. aspera and its potent antioxidant activity is believed to be mainly due to their redox properties, which play a pivotal role in neutralizing the inflammation in fish challenged with a pathogen bacterium. The enhanced survival rate of Nile tilapia challenged with $A$. hydrophila may be due to the activation of innate immune defense, due to the presence of different bioactive compounds and essential oils present in L. aspera that can break the lipid bilayer of the cell membrane, and its hydrophobic action resulting in losing the permeability and leakage of cell contents.

Based on the absence of histopathological changes in the treatment groups it is suggested that diet supplemented with $L$. aspera can exert a protective effect to the liver, the main organ for detoxification. Expression of inflammatory related gene cyclooxygenase-2 (COX-2) and antioxidant related gene glutathione reductase (GR) was evident after challenge test. COX-2 is involved in inflammatory response, and its 


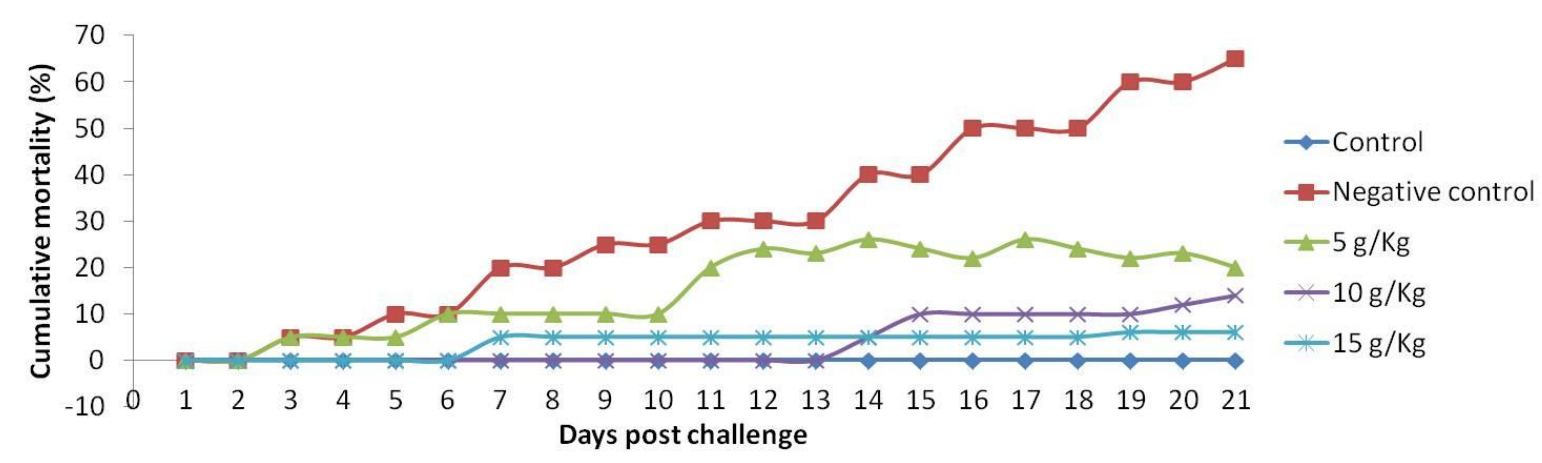

Figure 5. Survival rate (\%) of $O$. niloticus (mean $\pm S E M, n=20$ ) fed different concentrations of $L$. aspera during 21 days post challenge with $A$. hydrophila. Significant difference $(\mathrm{P}<0.05)$ from the control is indicated by asterisk.
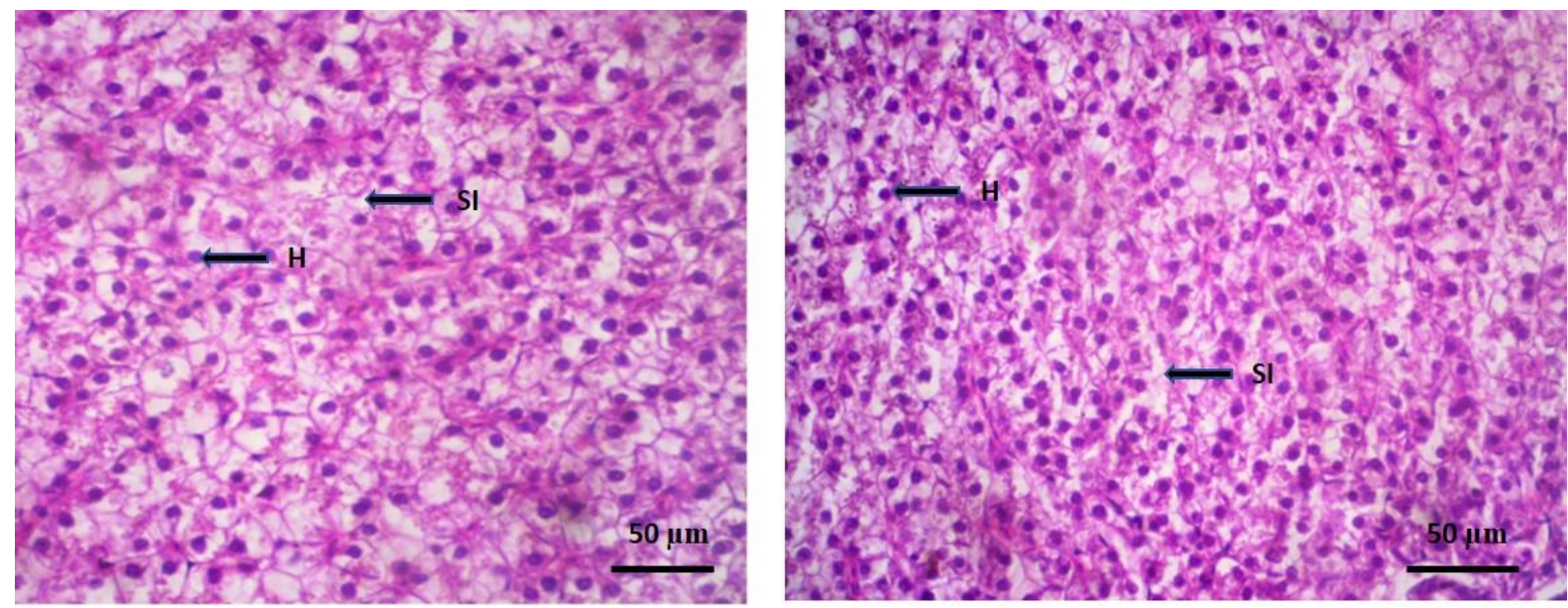

Figure 6a-b. Histology of liver section of $O$. niloticus fed control diet b: Histology of liver section of $O$. niloticus fed $L$. aspera $10 \mathrm{~g}$ $\mathrm{kg}^{-1}$ diet.

role in aquatic animals is that it acts in the arachidonic acid cascade which can eventually synthesize the inflammatory mediators called eicosanoids (Oxley et al., 2010). GR expression suggest that $L$. aspera enriched feed can augment the antioxidant capacity of fish and may neutralize the free radicals.

Inclusion of $L$. aspera at inclusion level of $10 \mathrm{~g} \mathrm{~kg}^{-1}$ enhanced the immunological parameters in Nile tilapia by exhibiting enhanced phagocytosis, complement activity, respiratory burst and lysozyme activity, and significantly enhanced growth performance compared with the control and other treatment groups. Results of the present study are in agreement with previous studies where Nile tilapia were fed different herbal supplements. Recent studies such as use of purslane (Portulaca oleracea) leaf powder enriched diet enhanced immune response, antioxidant activity and protection against $A$. hydrophila in Nile tilapia (AbdelRazak et al., 2019), and guava (Psidium guajava) extract improved growth, nutrient utilization, immunity and resistance against $A$. hydrophila of Nile tilapia (Omitoyin et al., 2019). These results and the present study proved the efficacy of herbal feed additives in health improvement of Nile tilapia. A possible explanation of the beneficial effect revealed in the present study might be due to the presence of bioactive phyto constituents in L. aspera. However, this hypothesis merits investigations, but it is worth to mention that the presence of secondary metabolites in $L$. aspera is responsible for the immune-modulation, for instance sterols can activate phagocytosis and lysozymal enzyme activity (Ghosal et al., 1989). According to previous studies, $L$. aspera leaves contain phenolic compounds like gallic acid and egallic acid; flavonoid compounds such as procyanidin, leucasin, acacetin and apigenin (Meghashri et al., 2010); phytosterols (beta-sitosterol); tannins (Kripa et al., 2011). The results of the present study are in accordance to those reported in velvet bean (M. pruriens) (Musthafa et al., 2018). The presence of tannins in L. aspera has been accredited to the plant's ability to hasten the healing of lesions and inflamed mucous membranes of aquatic organisms (Prajapati et al., 2010). Flavonoids are free radical scavengers that prevent oxidative cell damage, phytosterols are known to up-regulate the immune response (Meghashri, 2010). Thus, the presence of antioxidant components and other bioactive compounds might be responsible for the activity of $L$. aspera in ameliorating infections caused by pathogens (Kurian et al., 2020). Bindhu et al. (2014) noticed that immunological parameters including 


\section{Cox-2}

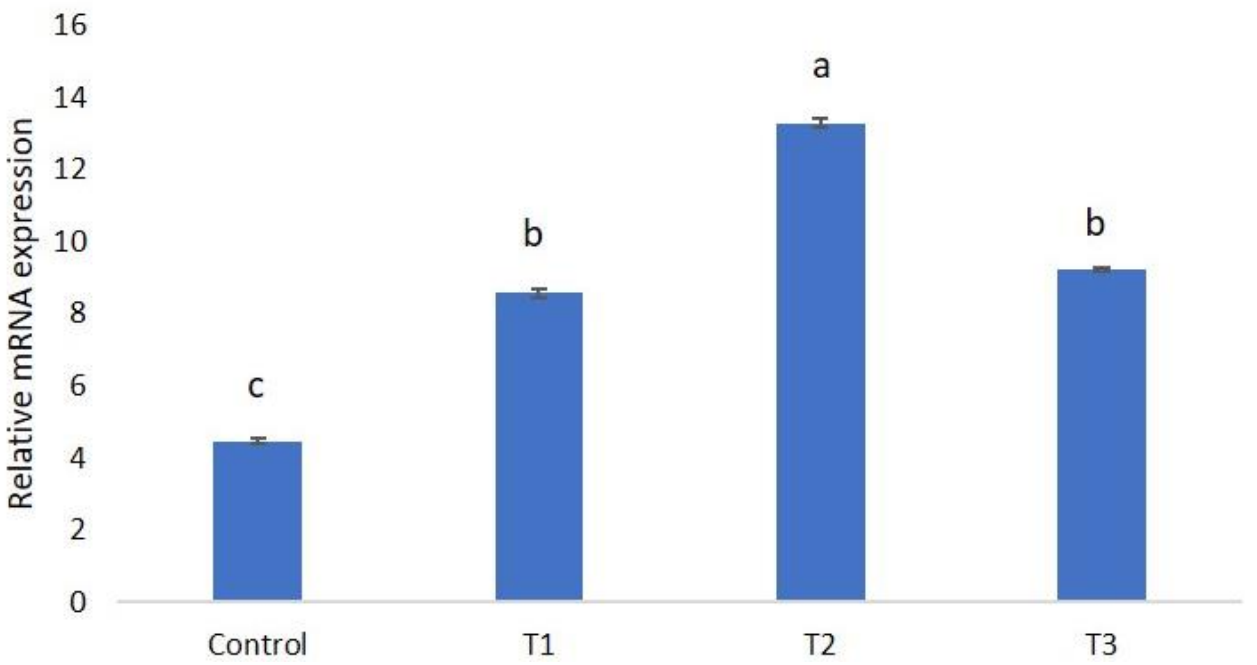

Figure 7a. Immune gene expression of COX-2 in O. niloticus

GR

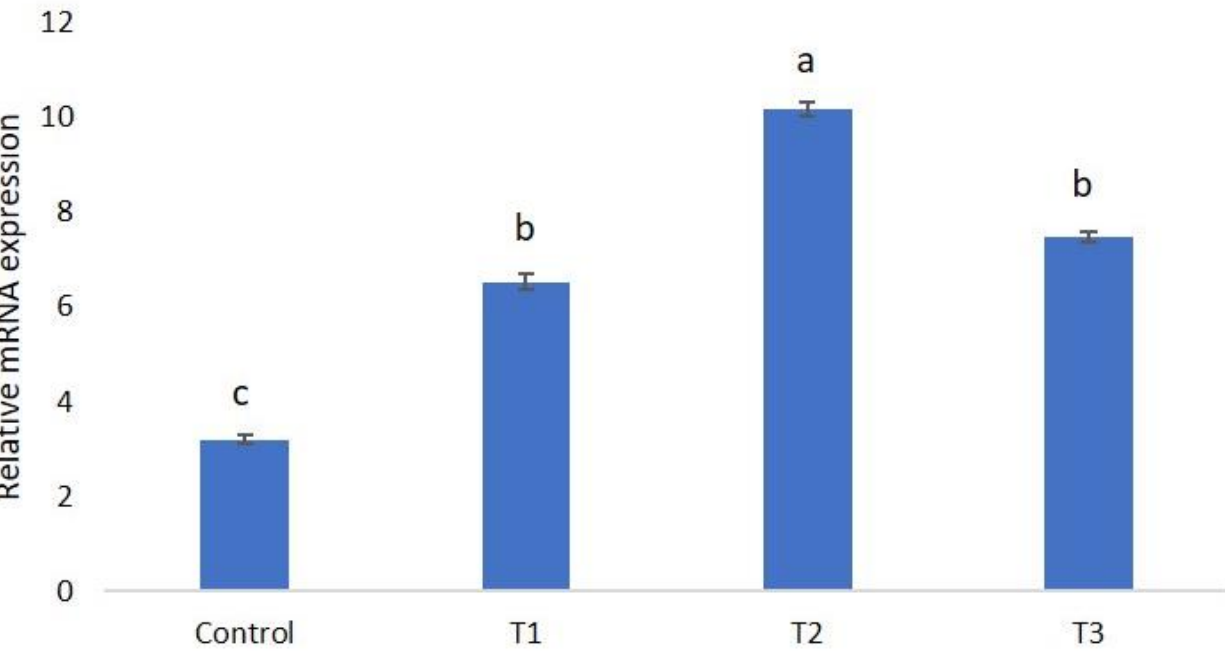

Figure 7b. Immune gene expression of GR in $O$. niloticus fed $10 \mathrm{~g} \mathrm{~kg}^{-1} \mathrm{~L}$. aspera enriched diet.

prophenol oxidase (proPO) activity, intracellular superoxide anion production and intra-agar lysozyme activities were significantly $(P<0.01)$ improved in the combined herbal extract of humming bird tree (Agathi grandiflora) with L. aspera at 300 and $400 \mathrm{mg} \mathrm{kg}^{-1}$ fed to Indian white shrimp (Fenneropenaeus indicus) after white spot syndrome virus challenge. Results from the current study indicated that $L$. aspera possess immunostimulatory properties, and this might be due to the strong occurrence of polyphenolic compounds such as alkaloids, flavonoids, tannins and steroids that serve as free radical inhibitors or scavenger. However, to fully conclude, further studies are needed.

In conclusion, $L$. aspera exhibits beneficial effects such as antioxidant and anti-inflammatory activities due to the presence of flavonoids, phytosterols, tannins, catechins, glycosides and phenolic compounds. Protection against bacterial infection makes this medicinal plant a better immune strengthening agent. This is mainly believed to be the action of polyphenols which are free radical scavengers. Compounds of $L$. aspera might be used as lead compounds for designing potent immune-modulatory herbal drug, which can be used as treatment of microbial diseases in various aquatic organisms. Hence, we conclude that $L$. aspera can be included in the diet of Nile tilapia for strengthening the immunity and promoting growth and disease resistance. Further scientific exploration on molecular aspect as well as immunological studies is needed to clarify the role of $L$. aspera in strengthening the health status of tilapia and to establish the therapeutic efficacy of this plant. 


\section{Ethical Statement}

All experiments were performed in compliance with the guidelines for animal welfare and the use of animals as prescribed by the Institutional Animal Ethics Committee (No. SOST/ PhD001/2019) of Kerala University of Fisheries and Ocean Studies, Kochi, Kerala, India.

\section{Funding Information}

The authors do not declare any funding information.

\section{Author Contribution}

First author: experimental design of the study, acquisition and interpretation of experimental data, and drafting of the manuscript; Second author: interpretation of the data, and reviewing of the manuscript; Third author: revising the article for important intellectual content and critical reviewing of the manuscript; Fourth author: Editing and finalization of the manuscript.

\section{Conflict of Interest}

The author(s) declare that they have no known competing financial or non-financial, professional, or personal conflicts that could have appeared to influence the work reported in this paper.

\section{Acknowledgements}

Amitha Kurian is thankful for the KUFOS PhD fellowship provided by the School of Ocean Science and Technology, Kerala University of Fisheries and Ocean Studies (KUFOS), Kochi, Kerala, India for completing this study.

\section{References}

Abdel-Razak, N., Awad, S.M., \& Abdel-Tawwab, M. (2019). Effect of dietary purslane (Portulaca oleracea L.) leaves powder on growth, immunostimulation, and protection of Nile tilapia, Oreochromis niloticus against Aeromonas hydrophila infection. Fish Physiology and Biochemistry, 45, 1-11. https://doi.org/10.1007/s10695-019-00685-8

Abdel-Tawwab, M., \& Abbass, F.E. (2017). Turmeric powder, Curcuma longa L., in common carp, Cyprinus carpio L., diets: Growth performance, innate immunity, and challenge against pathogenic Aeromonas hydrophila infection. Journal of the World Aquaculture Society, 48, 303-312. https://doi.org/ 10.1111/jwas.12349

Algammal, A.M., Mohamed, M.F., Tawfiek, B.A., Hozzein, W.N., El Kazzaz, W.M., \& Mabrok, M. (2020). Molecular Typing, Antibiogram and PCR-RFLP Based Detection of Aeromonas hydrophila Complex Isolated from Oreochromis niloticus. Pathogens, 22, 9(3):238. https://doi: 10.3390/pathogens9030238.
Algammal, A.M., Mabrok, M., Sivaramasamy, E., Youssef, F.M., Atwa, M.H., El-Kholy, A.W., Hetta, H.F., \& Hozzein, W.N. (2020). Emerging MDR-Pseudomonas aeruginosa in fish commonly harbor oprL and toxA virulence genes and

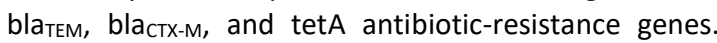
Scientific Reports, 29, 10(1):15961. https://doi: 10.1038/s41598-020-72264-4.

Algammal, A.M., El-Kholy, A.W., Riad, E.M., Mohamed, H.E., Elhaig, M.M., Yousef, S.A.A., Hozzein, W.N., \& Ghobashy, M.O.I. (2020). Genes Encoding the Virulence and the Antimicrobial Resistance in Enterotoxigenic and ShigaToxigenic $E$. coli Isolated from Diarrheic Calves. Toxins, 10, 12(6):383. https://doi: 10.3390/toxins12060383.

Algammal, A.M., El-Sayed, M.E., Youssef, F.M., Saad, S.A., Elhaig, M.M., Batiha, G.E., Hozzein, W.N., \& Ghobashy, M.O.I. (2020). Prevalence, the antibiogram and the frequency of virulence genes of the most predominant bacterial pathogens incriminated in calf pneumonia. AMB Express, 29, 10(1):99. https://doi: 10.1186/s13568020-01037-z.

Algammal, A.M., Enany, M.E., El-Tarabili, R.M., Ghobashy, M.O.I., \& Helmy, Y.A. (2020). Prevalence, Antimicrobial Resistance Profiles, Virulence and EnterotoxinsDeterminant Genes of MRSA Isolated from Subclinical Bovine Mastitis in Egypt. Pathogens, 9, 9(5):362. https://doi: 10.3390/pathogens9050362.

Abolghait, S.K., Fathi, A.G., Youssef, F.M., \& Algammal, A.M. (2020). Methicillin-resistant Staphylococcus aureus (MRSA) isolated from chicken meat and giblets often produces staphylococcal enterotoxin $B$ (SEB) in nonrefrigerated raw chicken livers. International Journal of Food Microbiology, 2, 328:108669.

https://doi: 10.1016/j.ijfoodmicro.2020.108669.

Antony, J.J., Nivedheetha, M., Siva, D., Pradeepha, G., Kokilavani, P., Kalaiselvi, S., Sankarganesh, A., Balasundaram, A., Masilamani, V., \& Achiraman, S. (2013). Antimicrobial activity of Leucas aspera engineered silver nanoparticles against Aeromonas hydrophila in infected Catla catla. Colloids and Surfaces B: Biointerfaces. 109, 20-24. https://doi.org/10.1016/j.colsurfb.2013.03.020

Awad, E., \& Awaad, A. (2017). Role of medicinal plants on growth performance and immune status in fish. Fish \& Shellfish Immunology, 67, 40-54. https://doi.org/ 10.1016/j.fsi.2017.05.034

Banu, S., Bhaskar, B., \& Balasekar, P. (2012). Hepatoprotective and antioxidant activity of Leucas aspera against $d$ galactosamine induced liver damage in rats. Pharmaceutical Biology, 50, 1592-1595. https://doi.org/ 10.3109/13880209.2012.685130

Behera, B.K., Pradhan, P.K., Swaminathan, T.R., Sood, N., Paria, P., Das, A., \& Jena, J.K. (2018). Emergence of tilapia lake virus associated with mortalities of farmed Nile tilapia Oreochromis niloticus (Linnaeus 1758) in India. Aquaculture, 484, 168-174. https://doi.org/10.1016/j.aquaculture.2017.11.025

Bindhu, F., Velmurugan, S., Donio, M., Babu, M., \& Citarasu, T. (2014). Influence of Agathi grandiflora active principles inhibit viral multiplication and stimulate immune system in Indian white shrimp Fenneropenaeus indicus against white spot syndrome virus infection. Fish \&Shellfish Immunology, 41, 482-492. https://doi.org/ 10.1016/j.fsi.2014.09.034

Bruce, T.J., \& Brown, M.L. (2017). A review of immune system components, cytokines, and immuno-stimulants in 
cultured finfish species. Open Journal of Animal Sciences, 7, 267-288. https://doi.org/ 10.4236/ojas.2017.73021

Burgos Aceves, M.A., Lionetti, L., \& Faggio, C. (2019). Multidisciplinary hematology as prognostic device in environmental and xenobiotic stress-induced response in fish. Science of the Total Environmental, 670, 11701183. https://doi.org/10.1016/j.scitotenv.2019.03.275

Cabello, F.C., Godfrey, H.P., Ivanova, L., Shah, S.Q.A., Henning Sørum, H., \& Tomova, A. (2020). Freshwater salmon aquaculture in Chile and transferable antimicrobial resistance. Environmental Microbiology, 22, 559-563. https://doi.org/10.1111/1462-2920.14891

Carbone D., \& Faggio, C. (2016). Importance of prebiotics in aquaculture as immunostimulants. Effects on immune system of Sparus aurata and Dicentrarchus labrax. Fish \& Shellfish Immunology, 54, 172-178. https://doi.org/10.1016/j.fsi.2016.04.011

Chuang, W.L., \& Pan, B.S. (2011). Anti-stress effects of Glycine tomentella Hayata in tilapia: inhibiting COX-2 expression and enhancing EPA synthesis in erythrocyte membrane and fish growth. Journal of Agricultural and Food Chemistry, 59, 9532-41. https://doi.org/10.1021/jf2017308

De Santis, C., Crampton, V.O., Bicskei, B., \& Tocher, D.R. (2015). Replacement of dietary soy- with air classified faba bean protein concentrate alters the hepatic transcriptome in Atlantic salmon (Salmo salar) parr. Comparative Biochemistry and Physiology. Part D Genomics Proteomics, 16, 48-58. https://doi.org/10.1016/j.cbd.2015.07.005

Dexiang, C., \& Ainsworth, A.J. (1991). Effect of temperature on the immune system of channel catfish (Ictalurus punctatus)-II. Adaptation of anterior kidney phagocytes to $10^{\circ} \mathrm{C}$. Comparative Biochemistry and Physiology. Part A: Comparative Physiology, 100, 913918.https://doi.org/10.1016/0300-9629(91)90314-3

Eddy, B.P. (2008). Cephalotrichous, fermentative gramnegative bacteria, the genus Aeromonas. Journal of Applied Microbiology, 23, 216 - 249. https://doi.org/10.1111/j.1365-2672.1960.tb00199.x

El-Sayed, M., Algammal, A., Abouel-Atta, M., Mabrok, M., \& Emam, A. (2019). Pathogenicity, genetic typing, and antibiotic sensitivity of Vibrio alginolyticus isolated from Oreochromis niloticus and Tilapia zillii. Revue de Médecine Vétérinaire, 170, 80-86.

Enany, M.E., Algammal, A.M., Shagar, G.I., Hanora, A.M., Elfeil, W.K., \& Elshaffy, N.M. (2018). Molecular typing and evaluation of Sidr honey inhibitory effect on virulence genes of MRSA strains isolated from catfish in Egypt. Pakistan Journal of Pharmaceutical Sciences, 31,18651870.

FAO, (2017). Globalfish - Analysis and information on world fish trade: Tilapia, in: Food and Agriculture Organization of the United Nations (Ed.)

Gholampour, T.E., Raieni, R.F., Larijani, M., Pouladi, M., Pagano, M., \& Faggio, C. (2020). The dietary effect of Vitex agnus-castus hydroalcoholic extract on growth performance, blood biochemical parameters, carcass quality, sex ratio and gonad histology in Zebrafish (Danio rerio). Applied Sciences, 10, 1402. https://doi.org/10.3390/app10041402

Ghosal, S., Srivastava, R.S., Bhattacharya, S.K., Upadhyay, S.N., Jaiswal, A.K., \& Chattopadhyay, U. (1989). Immunomodulatory and CNS effects of sitoindosides IX and $\mathrm{X}$, two new glycowithanolides from Withania somnifera. Phytotherapy Research, 3, 201-206. https://doi.org/10.1002/ptr.2650030510

Gobi, N., Vaseeharan, B., Rekha, R., Vijayakumar, S., \& Faggio C. (2018). Bioaccumulation, cytotoxicity and oxidative stress of the acute exposure selenium in Oreochromis mossambicus. Ecotoxicology and Environmental Safety, $162,147-159$

https://doi.org/10.1016/j.ecoenv.2018.06.070

Gu, D., Ma, G., Zhu, Y., Xu, M., Luo, D., Li, Y., Wei, H., Mu, X., Luo, J., \& Hu, Y. (2015). The impacts of invasive Nile tilapia (Oreochromis niloticus) on the fisheries in the main rivers of Guangdong Province, China. Biochemical Systematics and Ecology, 59, 1-7.

https://doi.org/10.1016/j.bse.2015.01.004

Harikrishnan, R., Kim, J.S., Kim, M.C., Balasundaram, C., \& Heo, M.S. (2011). Kalopanax pictus as feed additive controls bacterial and parasitic infections in kelp grouper, Epinephelus bruneus. Fish \& Shellfish Immunology, 31, 801-807. https://doi.org/10.1016/j.fsi.2011.07.017

Harikrishnan, R., Moon, Y.G., Kim, M.C., Kim, J.S., Heo, M.S., Balasundaram, C., \& Dharaneedharan, S. (2010). Phytotherapy of Aeromonas hydrophila-infected goldfish, Carassius auratus. Journal of the World Aquaculture Society, 41, 391-401. https://doi.org/10.1111/j.1749-7345.2010.00380.x

Hossein Hoseinifar, S., Shakouri, M., Yousefi, S., Van Doan, H., Shafiei, S., Yousefi, M., Mazandarani, M., Torfi Mozanzade, M., Tulino, M.G., \& Faggio, C. (2020). Humoral and skin mucosal immune parameters, intestinal immune related genes and antioxidant defense of rainbow trout (Oncorhynchus mykiss) fed dietary olive (Olea europea L.) waste. Fish \& Shellfish Immunology,100, 171-178. https://doi.org/10.1016/j.fsi.2020.02.067

Humason, G.L. (1979). Animal Tissue Techniques. 4th Edn., WH Freeman and Company, San Francisco, USA., pp: 3-331.

Janda, J.M., \& Abbott, S.L.(2010). The genus Aeromonas: Taxonomy, pathogenicity, and infection. Clinical Microbiology Reviews, 23, 35-73. https://doi.org/10.1128/CMR.00039-09

Kripa, K.G., Chamundeeswari, D., Thanka, J., Maheswara, U., \& Reddy, C. (2011). Modulation of inflammatory markers by the ethanolic extract of Leucas aspera in adjuvant arthritis. Journal of Ethnopharmacology, 134, 10241027. https://doi.org/10.1016/j.jep.2011.01.010

Kurian, A., Van Doan, H., Tapingkae, W., \& Elumalai, P. (2020). Modulation of mucosal parameters, innate immunity, growth and resistance against Streptococcus agalactiae by enrichment of Nile tilapia (Oreochromis niloticus) diet with Leucas aspera. Fish \& Shellfish Immunology, 97, 165-172. https://doi.org/10.1016/j.fsi.2019.12.043

Magnadottir, B. (2006). Innate immunity of fish (overview). Fish \& Shellfish Immunology, 20, 137-151. https://doi.org/10.1016/j.fsi.2004.09.006

Mahfouz, M.E. (2015). Ameliorative effect of curcumin on aflatoxin B1-induced changes in liver gene expression of Oreochromis niloticus. Molecular Biology, 49, 275-286. https://doi.org/10.1134/S0026893315020089

Mahmoud, H.K., Al-Sagheer, A.A., Reda, F.M., Mahgoub, S.A., \& Ayyat, M.S. (2017). Dietary curcumin supplement influence on growth, immunity, antioxidant status, and resistance to Aeromonas hydrophila in Oreochromis niloticus. Aquaculture, 475, 16-23. 
https://doi.org/10.1016/j.aquaculture.2017.03.043

Mbokane, E.M., \& Moyo, N.A.G. (2018). A preliminary investigation into the potential effect of Artemisia afra on growth and disease resistance in sub-adults of Oreochromis mossambicus. Aquaculture, 482, 197-202. https://doi.org/10.1016/j.aquaculture.2017.09.047

Meghashri, S., Vijay Kumar, H., \& Gopal, S. (2010). Antioxidant properties of a novel flavonoid from leaves of Leucas aspera. Food Chemistry,122, 105-110. https://doi.org/10.1016/j.foodchem.2010.02.023

Musthafa, M.S., Asgari, S.M., Kurian, A., Elumalai, P., Jawahar Ali, A.R., Paray, B.A., \& Al-Sadoon, M.K. (2018). Protective efficacy of Mucuna pruriens (L.) seed meal enriched diet on growth performance, innate immunity, and disease resistance in Oreochromis mossambicus against Aeromonas hydrophila. Fish \& Shellfish Immunology, 75, 374-380.

https://doi.org/10.1016/j.fsi.2018.02.031

Musthafa, M.S., Jawahar Ali, A.R., Arun Kumar, M.S., Paray, B.A., Al-Sadoon, M.K., Balasundaram, C., \& HariKrishnan, R. (2017). Effect of Cucurbita mixta (L.) seed meal enrichment diet on growth, immune response and disease resistance in Oreochromis mossambicus. Fish \& Shellfish Immunology, 68,509-515. https://doi.org/10.1016/j.fsi.2017.07.050

Nath S., Matozzo V., Bhandari D., \& Faggio C. (2018). Growth and liver histology of Channa punctatus exposed to a common biofertilizer. Natural Product Research, 33, 1591-1598. https://doi.org/10.1080/14786419.2018.1428586

Newaj-Fyzul, A., \& Austin, B. (2014). Probiotics, immunostimulants, plant products and oral vaccines, and their role as feed supplements in the control of bacterial fish diseases. Journal of Fish Diseases, 38, 937955. https://doi.org/10.1111/jfd.12313

Nya, E.J., \& Austin, B. (2009). Use of garlic, Allium sativum, to control Aeromonas hydrophila infection in rainbow trout, Oncorhynchus mykiss (Walbaum). Journal of Fish Diseases, 32, 963-970. https://doi.org/10.1111/j.13652761.2009.01100.x

Ojha, M.L., Chadha, N.K., Saini, V.P., Damroy, S., Chandraprakash, N., \& Sawant, P.B. (2014). Effect of ethanolic extract of Mucuna pruriens on growth, metabolism and immunity of Labeo rohita (Hamilton, 1822) fingerlings. International Journal of Fauna and Biological Studies, 1,1-9.

Omitoyin, B.O., Ajani, E.K., Orisasona, O., Bassey, H.E., Kareem, K.O., \& Osho, F.E. (2019). Effect of guava Psidium guajava (L.) aqueous extract diet on growth performance, intestinal morphology, immune response and survival of Oreochromis niloticus challenged with Aeromonas hydrophila. Aquaculture Research, 50, 18511861. https://doi.org/10.1111/are.14068

Oxley, A., Jolly, C., Eide, T., Jordal, A.E., Svardal, A., \& Olsen, R.E. (2010). The combined impact of plant-derived dietary ingredients and acute stress on the intestinal arachidonic acid cascade in Atlantic salmon (Salmo salar). British Journal of Nutrition,103, 851-861. https://doi.org/10.1017/S0007114509992467

Parry, R.M., Chandan, R.C., \& Shahani, R.M. (1965). A rapid sensitive assay of muramidase. Proceedings of the Society for Experimental Biology and Medicine, 119,384386. https://doi.org/10.3181/00379727-119-30188

Pearse, A.G.E. (1968). Histochemistry: Theoretical and Applied. 3rd Edn., J and A Churchill Ltd., London, pp: 13-
102.

Prajapati, M.S., Patel, J.B., Modi, K., \& Shah, M.B. (2010). Leucas aspera: A review. Pharmacognosy Review, 4, 8587.https://doi.org/10.4103/0973-7847.65330

Rashidian, G., Bahrami Gorji, S., Naderi Farsani, M., Prokic, M.D., \& Faggio, C. (2018). The oak (Quercus brantii) acorn as a growth promotor for rainbow trout (Oncorhynchus mykiss): growth performance, body composition, liver enzymes activity and blood biochemical parameters. Natural Product Research, 23, 1-11. https://doi.org/10.1080/14786419.2018.1538994.

Praveen, P.K., Debnath, C., Shekhar, S., Dalai, N., \& Ganguly, S. (2016). Incidence of Aeromonas spp. infection in fish and chicken meat and its related public health hazards: A review. Veterinary world, 9(1), 6-11. https://doi.org/10.14202/vetworld.2016.6-11

Rashidian, G., Kajbaf, K., Prokić, M., \& Faggio, C. (2019). Extract of common mallow (Malvae sylvestris) enhances growth, immunity, and resistance of rainbow trout (Oncorhynchus mykiss) fingerlings against Yersinia ruckeri infection. Fish \& Shellfish Immunology, 96, 254261. https://doi.org/10.1016/j.fsi.2019.12.018

Rashidian, G., Rainis, S., Prokic, M., \& Faggio, C. (2020). Effects of different levels of carotenoids and light sources on swordtail fish (Xiphophorus helleri) growth, survival rate and reproductive parameters. Natural Product Research, 3, 1-12. https://doi.org/10.1080/14786419.2020.1723091

Reverter, M., Bontemps, N., Lecchini, D., Banaigs, B., \& Sasal, P. (2014). Use of plant extracts in fish aquaculture as an alternative to chemotherapy: Current status and future perspectives. Aquaculture, 433, 50-61. https://doi.org/10.1016/j.aquaculture.2014.05.048

Ring $\varnothing$, E., Olsen, R.E., Jensen, I, Romero, J, \& Lauzon, H.L. (2014). Application of vaccines and dietary supplements in aquaculture: possibilities and challenges. Reviews in Fish Biology and Fisheries,24,1005-1032. https://doi.org/10.1007/s11160-014-9361-y

Saurabh, S., \& Sahoo, P.K. (2008). Lysozyme: an important defence molecule of fish innate immune system. Aquaculture Research, 39, 223-239. https://doi.org/10.1111/j.1365-2109.2007.01883.x

Secombes, C.J., Stolen, J.S., Fletcher, T.C., Anderson, D.P., \& Roberson, B.S. (1990). Isolation of salmonid macrophages and analysis of their killing activity. Techniques in Fish Immunology, Fair Haven, SOS Publications, New Jersey, USA. 1,137-155.

Semple, S.L., Kellendonk, C.J., Al-Hussinee, L., Maclnnes, J.I., Lumsden, J.S., \& Dixon, B. (2018). Serum IgM, MH class $\| \beta$ genotype and respiratory burst activity do not differ between rainbow trout families displaying resistance or susceptibility to the coldwater pathogen, Flavobacterium psychrophilum. Aquaculture, 483,131140. https://doi.org/10.1016/j.aquaculture.2017.10.020

Seyfried, E.E., Newton, R.J., Rubert, K.F., Pedersen, J.A., \& McMahon, K.D. (2010). Occurrence of tetracycline resistance genes in aquaculture facilities with varying use of oxytetracycline. Microbial Ecology, 59,799-807. https://doi.org/10.1007/s00248-009-9624-7

Suganya, G., Karthi, S., \& Shivakumar, M.S. (2014). Larvicidal potential of silver nanoparticles synthesized from Leucas aspera leaf extracts against dengue vector Aedes aegypti. Parasitology Research. 113, 1673-1679. https://doi.org/10.1007/s00436-014-3811-2

Teepica, P.D., \& Ponnuraj, S. (2015). Bioencapsulation of 
Artemia nauplii using medicinal plant extracts for promoting growth in Danio rerio fry. https ://eprints.cmfri.org.in. pdf.

Van Doan, H., Hoseinifar, S.H., Tapingkae, W., Tongsiri, S., \& Khamtavee, P. (2016). Combined administration of low molecular weight sodium alginate boosted immunomodulatory, disease resistance and growth enhancing effects of Lactobacillus plantarum in Nile tilapia (Oreochromis niloticus). Fish \& Shellfish Immunology, 58, 678-685. https://doi.org/10.1016/j.fsi.2016.10.013

Van Doan, H., Hoseinifar, S.H., Elumalai, P., Tongsiri, S., Chitmanat, C., Jaturasitha, S., \& Doolgindachbaporn, S. (2018). Effects of orange peels derived pectin on innate immune response, disease resistance and growth performance of Nile tilapia (Oreochromis niloticus) cultured under indoor biofloc system. Fish \& Shellfish Immunology, 80, 56-62. https://doi.org/10.1016/j.fsi.2018.05.049

Van Doan, H., Hoseinifar, S.H., Srigarm, K., Jaturasitha, S., Yuangsoi, B., Dawood, M.A.O., Esteban, M.A., Ringo, E., \& Faggio, C. (2019). Effects of Assam tea extract on growth, skin mucus, serum immunity and disease resistance of Nile tilapia (Oreochromis niloticus) against Streptococcus agalactiae. Fish \& Shellfish Immunology, 93, 428-435. https://doi.org/10.1016/j.fsi.2019.07.077

Van Doan H., Hoseinifar S.H., Ringo E., Esteban M.A., Dadar M., Dawood M.A.O., \& Faggio C. (2019). Host-associated probiotics: a key factor in sustainable aquaculture. Reviews in Fisheries Science \& Aquaculture, 28, 16-42. https://doi.org/10.1080/23308249.2019.1643288

Van Doan, H., Hoseinifar, S.H., Faggio, C., Chitmanat, C., Mai, N.T., Jaturasitha, S., \& Ring $\varnothing$, E. (2018). Effects of corncob derived xylooligosaccharide on innate immune response, disease resistance, and growth performance in Nile tilapia (Oreochromis niloticus) fingerlings. Aquaculture, 495, 786-793. https://doi.org/10.1016/j.aquaculture.2018.06.068

Van Hai, N. (2015). The use of medicinal plants as immunostimulants in aquaculture: A review. Aquaculture, 446, 88-96.

https://doi.org/10.1016/j.aquaculture.2015.03.014

Wang, G.X., Jiang, D., Zhou, Z., Zhao, Y.K., \& Shen, Y.H. (2009). In vivo assessment of anthelmintic efficacy of ginkgolic acids (C13:0, C15:1) on removal of Pseudodactylogyrus in European eel. Aquaculture,297,38-43.

https://doi.org/10.1016/j.aquaculture.2009.09.012

Wu, C.C., Liu, C.H., Chang, Y.P., \& Hsieh, S.L. (2010). Effects of hot-water extract of Toona sinensis on immune response and resistance to Aeromonas hydrophila in Oreochromis mossambicus. Fish \& Shellfish Immunology, 29,258-263. https://doi.org/10.1016/j.fsi.2010.04.021

Yano, T., Stolen, J.S., Fletcher, T.C., Anderson, D.P., Hattari, S.C., \& Rowley, A.F. (1992). Assay of hemolytic complement activity (Eds.). Techniques in Fish Immunology, SOS Publications, Fair Haven, NJ. 131-141.

Yilmaz, E. (2019). Effects of dietary anthocyanin on innate immune parameters, gene expression responses, and ammonia resistance of Nile tilapia (Oreochromis niloticus). Fish \& Shellfish Immunology, 93, 694-701. https://doi.org/10.1016/j.fsi.2019.08.033

Yin, G., Cao, L., Xu, P., Jeney, G., Nakao, M., \& Lu, C. (2011). Hepatoprotective and antioxidant effects of Glycyrrhiza glabra extract against carbon tetrachloride $\left(\mathrm{CCl}_{4}\right)^{-}$ induced hepatocyte damage in common carp (Cyprinus carpio). Fish Physiology and Biochemistry, 37, 209-216. https://doi.org/10.1007/s10695-010-9436-1

Yousefi, M., Hoseini, S.M., Vatnikov, Y.A., Kulikov, E.V., \& Drukovsky, S.G. (2019). Rosemary leaf powder improved growth performance, immune and antioxidant parameters, and crowding stress responses in common carp (Cyprinus carpio) fingerlings. Aquaculture, 505, 473480. https://doi.org/ 10.1016/j.aquaculture.2019.02.070

Zapata, A., Diez, B., Cejalvo, T., Gutierrez-De Frias, C., \& Cortes, A. (2006). Ontogeny of the immune system of fish. Fish \& Shellfish Immunology, 20, 126-136. https://doi.org/ 10.1016/j.fsi.2004.09.005 